\title{
Sweet Pepper (Capsicum annuum L.) Productivity: Quality and Soil Health in Sub-Temperate Zone of North-Western Himalayas
}

\author{
Kajal Sharma*, A.K. Sharma and Shivender Thakur \\ Department of Vegetable Science, Dr YS Parmar University of Horticulture and Forestry, \\ Nauni, Solan (HP), India \\ *Corresponding author
}

A B S T R A C T

\begin{tabular}{l} 
K e y w or d s \\
Sweet pepper, \\
Bio-inoculation, \\
Growing media, \\
Substrates, \\
Transplanting dates. \\
\hline Article Info \\
\hline $\begin{array}{l}\text { Accepted: } \\
\text { 04 July 2017 } \\
\text { Available Online: } \\
\text { 10 September } 2017\end{array}$ \\
\hline
\end{tabular}

A field trial was conducted to study the effect of bio-inoculation, growing media and transplanting dates on fruit yield, quality and post-harvest soil health in sweet pepper. Bioinoculation resulted in significant increased yield $(265.43 \mathrm{q} / \mathrm{ha})$ and quality (vitamin C$114.89 \mathrm{mg} / 100 \mathrm{~g})$ with reduced incidence of fruit $\operatorname{rot}(5.61 \%)$ and fruit borer $(3.02 \%)$ vis a vis corresponding values of $240.17 \mathrm{q} / \mathrm{ha}, 110.28 \mathrm{mg} / 100 \mathrm{~g}, 6.55 \%$ and $3.65 \%$, for uninoculation. Additionally, bio-inoculation significantly increased availability of NPK $(384.95,81.37$ and $391.33 \mathrm{~kg} / \mathrm{ha})$ with improved microbial population than untreated plots (369.26, 76.62 and $372.44 \mathrm{~kg} / \mathrm{ha}$ ). Growing media used for raising seedlings showed no significant effects on these parameters excepting enhanced microbial count in soilless plots $\left(102.16 \times 10^{5} \mathrm{cfu} / \mathrm{g}\right)$ over soil medium $\left(98.83 \times 10^{5} \mathrm{cfu} / \mathrm{g}\right)$. Transplanting on April, 05 recorded maximum yield (326.69 q/ha), TSS $\left(5.29^{\circ} \mathrm{B}\right)$, ascorbic acid content (128.86 $\mathrm{mg} / 100 \mathrm{~g}$ ) with minimum incidence of fruit rot $(4.94 \%)$ and fruit borer $(2.53 \%)$ comparing late transplanting. The study concluded that bio-inoculated plants developed from seedlings evolved in either of the growing media when transplanted on an earliest date i.e. April, 05 instigated upgraded pepper yield and quality with good buildup of postharvest nutrient status.

\section{Introduction}

Sweet pepper (Capsicum annuиm L.), a member of Solanaceae, is a native of Mexico with secondary centre of origin in Guatemala (Bukasov, 1930). Sweet pepper has attained a status of high value crop in recent years and occupies a pride place among vegetables because of delicacy and pleasant flavor coupled with rich content of ascorbic acid (Chassy et al., 2006).

It was introduced in India by the Britishers in $19^{\text {th }}$ century in Shimla hills of Himachal Pradesh (Greenleaf, 1986), and later on, its cultivation spread to other sub-montane tracks of other states of India viz. Jammu and Kashmir, Uttarakhand, Arunachal Pradesh and Darjeeling district of West Bengal, Maharashtra, Karnataka, Tamil Nadu and Bihar, occupying an area of 30 thousand hectares with a production of 172 thousand metric tonnes (Anonymous, 2016). In Himachal Pradesh, it is extensively grown as cash crop in Solan, Shimla, Mandi and Chamba districts of state during summer and rainy seasons over an area of 2.07 thousand hectares with production of 34.13 thousand 
metric tonnes (Anonymous, 2016) and thereby, boosting economy of farmers of hilly regions through 'off season' supplies to the adjoining plains of Chandigarh, Punjab, Haryana and National Capital Region of Delhi.

The management of disease and nutrient needs of the crop in nursery stage plays an important role in maintaining the health and vigor of the seedlings which in turn affects the quantity and quality of the final product (Shiau et al., 1999). Scrupulous farming operations that asserted high yield and quality necessitated immense application of chemical fertilizers, herbicides and pesticides, which are expensive and create human, animal problems and environmental hazards. A new approach in sustainable production systems is use of plant growth promoting rhizobacteria (PGPR) microorganisms to minimize the use of mineral fertilizers/pesticides and maximize plant growth. PGPR are naturally occurring soil bacteria that aggressively colonize plant roots and benefit plants by providing growth promotion. There are numerous reports on plant growth promotion and yield augmentation with PGPR mainly by directly affecting plant metabolism or availability of nutrients (Bashan and Levanony, 1990) and indirectly by suppressing soil borne pathogens or by stimulating plant defences, by a mechanism called induced systematic resistance (Kloepper et al., 1993)

Additionally, suitable growing media for rising of transplants is indispensable for production of vegetable crops as it directly governs the evolution and later perpetuation of large unostentatious rooting system. Further, planting time is a vital factor in regulating the crop yields, as delay in planting results in decrease of length of vegetative phase, decrease of assimilation, early flowering and increase of flowers loss and infertility (Sreelatha et al., 1997).
Therefore, the present investigation was undertaken to determine the effect of bioinoculation, growing media and different transplanting dates on sweet pepper fruit yield, quality, incidence of Phytophthora fruit rot, fruit borer and post-harvest soil health under mid hill conditions of Himachal Pradesh.

\section{Materials and Methods}

\section{Location and climate}

The present investigation was carried out at Dr YS Parmar University of Horticulture and Forestry, Nauni, Solan (HP), India during kharif season of 2016. The place is situated at $35^{\circ} 5^{\prime} \mathrm{N}$ latitude and of $77^{\circ} 11^{\prime} \mathrm{E}$ at an elevation of $1270 \mathrm{~m}$ above mean sea level and agro-climatically, characterized by sub-temperate to sub-tropical climate with moderate rainfall (1000-1300 mm).

\section{Experimental layout}

The Randomised Block Design factorial experiment consisted of three factors; i) bioinoculation ( $\mathrm{B}_{1}$-inoculation and $\mathrm{B}_{2}$-uninoculation) ii) two growing media $\left(\mathrm{M}_{1^{-}}\right.$ soilless medium in pro-trays and $\mathrm{M}_{2-}$ soil medium in earthen pots) and iii) three transplanting dates $\left(\mathrm{D}_{1^{-}} 5^{\text {th }}\right.$ April, $\mathrm{D}_{2^{-}}-20^{\text {th }}$ April and $\mathrm{D}_{3^{-}} 5^{\text {th }}$ May).

In pro-trays, a mixture of coco peat, vermiculite and perlite (3:1:1) was used whereas; in earthen pots, it comprised of mixture of field soil and FYM $(2: 1)$ as a medium of growth.

\section{Cultural management}

Seeds of sweet pepper cultivar 'Solan Bharpur' were soaked in culture broth of bacterium (Bacillus subtilis - cell density $10^{8} \mathrm{cfu} / \mathrm{ml}$ ) in sterilized Petri-plates for 3-4 
hours. Both inoculated and un-inoculated seeds as per treatment were sown in two substrate media at three week interval commencing February 01, 2016 under polytunnel to provide protection against danger of frost or low temperature.

Seedlings that scored $10+\mathrm{cm}$ height or 5 true leaves were given bacterium or sterilized water dip as per treatment and transplanted at $60 \times 45 \mathrm{~cm}$ spacing on dates as per treatments above.

\section{Observation recorded}

The observations on pepper fruit yield, quality parameters viz. TSS, ascorbic acid as well as disease and pest incidence (incidence of Phytophthora fruit rot and fruit borer) were recorded. Soil physico-chemical analysis for properties viz. pH, EC, OC, available N, P and $\mathrm{K}$ content and total microbial count was also undertaken to know post-harvest status of soil. Ascorbic acid content was estimated by 2, 6-dichlorophenol-indophenol visual method given by AOAC (1970).

Soil $\mathrm{pH}$ was determined using 1:25 soil water suspension by electrical digital $\mathrm{pH}$ meter and method given by Jackson (1973) employed for determining electrical conductivity. Organic carbon (OC) was determined by method of Walkley and Black (1934). Available N, P and $\mathrm{K}$ were determined by methods of Subbiah and Asija (1956), Olsen et al., (1954) and Merwin and Peech (1951), respectively. Microbial count was determined by method given by Subba Rao (1999).

\section{Statistical analysis}

The data obtained were subjected to analysis of variance as described by Panse and Sukhatme (2000) for Randomized Block Design (Factorial), by using MS-Excel and OPSTAT (Sheoren et al., 1998).

\section{Results and Discussion}

\section{Yield}

A perusal of data (Table 1) revealed that bioinoculated plants recorded 10.52 per cent significant increase in yield (265.43 q/ha) visa-vis un-inoculated plants which yielded @ $240.17 \mathrm{q} / \mathrm{ha}$. The results were agreed with the findings of Mirik et al., (2008) and Gul et al., (2012), who reported increased yield in the presence of PGPR. As far as the growing media of nursery transplants were concerned, there were no significant variations between seedling grown on soil or soilless medium. Among different transplanting dates, highest yield (326.69 $\mathrm{q} / \mathrm{ha})$ was observed with $1^{\text {st }}$ planting time (April, 05) whereas, late transplanting on May, 05 resulted in least yield (173.42) of pepper fruits. Similar results were also observed by Bevacqua and Vanleeuwen (2003), Peyvast (2001) and Hossain (2001), who reported that earliest planting date resulted in a significantly higher early and total yield compared to the later planting dates.

The increase in fruit yield and other parameters by inoculation with bacterium (Bacillus subtilis) were potentially due to readily availability of nutrients, producing siderophores that chelate iron and make it available to the plant root; solubilising minerals such as phosphorous, producing phytohormones or growth regulators that cause crops to have greater amounts of fine roots which have the effect of increasing the absorptive surface of plant roots for uptake of water and nutrients and synthesizing some compounds or enzymes that can develop plant growth and by decreasing the deleterious effects of phytopathogenic organisms on crop yield (Glick, 1995).

Seedlings transplanted at an earlier date (April, 05) gave higher fruit yield; which is 
attributable to exposure of plants to conducive temperature and optimum relative humidity which allows plants to better utilize the resources (soil nutrients and soil moisture) for longer duration resulting in higher fruit setting, better size and weight owing to their longer gestation period and ultimately the higher fruit yield (More et al., 2014). Further, in delayed planting, plant vegetative growth stage faces intense heat of the season which results in decrease of vegetative organs, lessen assimilation, increased flowers loss, infertility, shorten harvest duration and consequently reduced fruit yield (Sreelatha et al., 1997).

\section{Quality}

As envisaged through table 1, TSS was not significantly influenced by inoculation with bacterium. However, increased ascorbic acid content $(114.89 \mathrm{mg} / 100 \mathrm{~g})$ was noted from the bio-inoculated plants. These results are in accordance with Singh et al., (2015), who obtained the highest value of ascorbic content $(34.59 \mathrm{mg} / 100 \mathrm{~g})$ with the application of biofertilizers (Azotobacter and PSB). Plants developed from seedlings raised on soilless medium in pro-trays recorded no significant variation in TSS and ascorbic acid content over soil substrate in earthen pots.

However, TSS (5.92 $\left.{ }^{\circ} \mathrm{B}\right)$ and ascorbic acid $(128.86 \mathrm{mg} / 100 \mathrm{~g})$ were found to be maximum from the plants transplanted on April, 05 as compared to successive transplanting dates. These results are in accordance with Bhardwaj (1993) and Jeevansab (2000).

The most probable reason for increased synthesis of ascorbic acid content by PGPR application might be due to increase in the efficiency of microbial inoculants to secrete growth promoting substances, which might have accelerated the physiological process and the activity of ascorbic acid oxidase enzyme causing marked improvement in Vitamin-C content (Chand et al., 2015).

Early planting showed marked effect in increasing the TSS and ascorbic acid content which was evident from the fact that early planted crop have strenuous vegetative growth with deep green colour of foliage which advocated higher photosynthetic activity leading to considerable accumulation of food material i.e. carbohydrates and thus, resulted in more synthesis of TSS and ascorbic acid content (Vidya et al., 2013).

\section{Disease and pest incidence}

As evident from table 1, the incidence of Phytophthora fruit rot $(5.61 \%)$ and fruit borer $(3.02 \%)$ appeared to be lower in bioinoculated plants than un-inoculated ones. Lamsal et al., (2012) also reported that bacterial isolates belonging to Bacillus sp. and Paenibacillus sp. exert antagonistic activity against Colletotricum acutatum. Similarly, Murphy et al., (2000) reported that seed treatment of tomato with several Bacillus PGPR species caused significant reduction in white nymph populations densities. However, there were no significant variations found between two growing substrates. As far as transplanting dates were concerned, early transplanting (April, 05) recorded minimum incidence of Phytophthora fruit rot (4.94\%) and fruit borer $(2.53 \%)$. Similar results were also found by Kethran et al., (2014) and Sujay and Giraddi (2014) that late transplanted crop was liable for heavy infestation by insect pests and mites.

The significant reduction in pest and disease incidence in inoculated plants showed that applied PGPR act as a bio-control agent through various mechanisms such as inhibition of microorganisms that have a negative effect on plant growth (by niche 
exclusion) viz. hydrolysis of molecules released by pathogens, synthesis of enzymes that hydrolyse fungal cell walls, synthesis of hydrogen cyanide $(\mathrm{HCN})$, improvement of symbiotic relationships with mycorrhizal fungi and degradation of toxin produced by pathogen and induced systemic resistance (Das et al., 2013).

Table.1 Effect of bio-inoculation, growing media and transplanting dates on fruit yield, total soluble solids, ascorbic acid content, Phytophthora fruit rot and fruit borer

\begin{tabular}{|c|c|c|c|c|c|}
\hline Treatment & $\begin{array}{c}\text { Yield } \\
\text { (q/hectare) }\end{array}$ & $\begin{array}{c}\text { TSS } \\
\left({ }^{\circ} \text { Brix }\right)\end{array}$ & $\begin{array}{l}\text { Ascorbic } \\
\text { acid } \\
(\mathbf{m g} / 100 g)\end{array}$ & $\begin{array}{c}\text { Phytophthora } \\
\text { fruit rot } \\
(\%)\end{array}$ & $\begin{array}{c}\text { Fruit borer } \\
(\%)\end{array}$ \\
\hline \multicolumn{6}{|l|}{ A. Bio-inoculation } \\
\hline Inoculation & 265.43 & 5.35 & 114.89 & $5.61(2.56)$ & $3.02(1.99)$ \\
\hline Un- inoculation & 240.17 & 5.43 & 110.28 & $6.55(2.74)$ & $3.65(2.15)$ \\
\hline $\mathrm{CD}(\mathrm{P} \leq \mathbf{0 . 0 5 \%})$ & 3.88 & NS & 3.01 & 0.09 & 0.06 \\
\hline \multicolumn{6}{|l|}{ B. Growing media } \\
\hline Soilless in pro-trays & 253.34 & 5.41 & 113.32 & $5.86(2.61)$ & $3.24(2.05)$ \\
\hline Soil in earthen pot & 252.26 & 5.37 & 111.85 & $6.30(2.69)$ & $3.43(2.10)$ \\
\hline $\mathrm{CD}(\mathrm{P} \leq \mathbf{0 . 0 5 \%})$ & NS & NS & NS & NS & NS \\
\hline \multicolumn{6}{|c|}{ C. Transplanting dates } \\
\hline April, 05 & 326.69 & 5.92 & 128.86 & $4.94(2.43)$ & $2.53(1.87)$ \\
\hline April, 20 & 258.29 & 5.40 & 112.57 & $5.87(2.61)$ & $3.40(2.09)$ \\
\hline May, 05 & 173.42 & 4.85 & 96.31 & $7.43(2.90)$ & $4.07(2.25)$ \\
\hline $\mathrm{CD}(\mathrm{P} \leq \mathbf{0 . 0 5 \%})$ & 4.76 & 0.33 & 3.69 & 0.11 & 0.07 \\
\hline
\end{tabular}

Table.2 Effect of bio-inoculation, growing media and transplanting dates on $\mathrm{pH}, \mathrm{EC}, \mathrm{OC}$, available NPK and microbial count in soil

\begin{tabular}{|c|c|c|c|c|c|c|c|}
\hline Treatment & pH & $\begin{array}{c}\text { EC } \\
(\mathrm{DS} / \mathbf{m})\end{array}$ & $\begin{array}{c}\text { Organic } \\
\text { carbon } \\
(\%)\end{array}$ & $\begin{array}{c}\mathbf{N} \\
(\mathrm{Kg} / \mathrm{ha})\end{array}$ & $\begin{array}{c}\mathbf{P} \\
(\mathrm{kg} / \mathrm{ha})\end{array}$ & $\begin{array}{c}\text { K } \\
\text { (kg/ha) }\end{array}$ & $\begin{array}{c}\text { Microbial } \\
\text { count } \\
\left(10^{5} \mathrm{cfu} / \mathrm{g}\right)\end{array}$ \\
\hline \multicolumn{8}{|l|}{ A. Bio-inoculation } \\
\hline Inoculation & 6.71 & 0.43 & 1.70 & 384.95 & 81.37 & 391.33 & 112.57 \\
\hline Un- inoculation & 6.73 & 0.41 & 1.67 & 369.26 & 76.62 & 372.44 & 88.42 \\
\hline $\mathrm{CD}(\mathrm{P} \leq \mathbf{0 . 0 5 \%})$ & NS & NS & NS & 6.54 & 1.12 & 2.53 & 2.10 \\
\hline \multicolumn{8}{|l|}{ B. Growing media } \\
\hline Soilless in pro-trays & 6.73 & 0.42 & 1.67 & 377.90 & 78.99 & 382.24 & 102.16 \\
\hline Soil in earthen pot & 6.71 & 0.42 & 1.69 & 376.31 & 78.99 & 381.52 & 98.83 \\
\hline $\mathrm{CD}(\mathrm{P} \leq \mathbf{0 . 0 5 \%})$ & NS & NS & NS & NS & NS & NS & 2.10 \\
\hline \multicolumn{8}{|c|}{ C. Transplanting dates } \\
\hline April, 05 & 6.71 & 0.42 & 1.68 & 378.48 & 79.08 & 380.90 & 100.50 \\
\hline April, 20 & 6.73 & 0.41 & 1.70 & 374.13 & 78.71 & 381.85 & 99.87 \\
\hline May, 05 & 6.71 & 0.43 & 1.67 & 378.71 & 79.19 & 382.89 & 101.13 \\
\hline $\mathrm{CD}(\mathrm{P} \leq \mathbf{0 . 0 5 \%})$ & NS & NS & NS & NS & NS & NS & NS \\
\hline
\end{tabular}


The high pest population in late planted crop might be due to high temperature coupled with high relative humidity. Similar results were reported by Aheer et al., (1994) that the incidence and development of disease and pest is dependent upon the prevailing physical environmental factors and crop stand and spread immensely during the favourable weather conditions causing huge damage.

\section{Soil health}

\section{pH, EC and OC}

The data presented in table 2 explicit that none of the tried treatment influenced $\mathrm{pH}, \mathrm{EC}$ and $\mathrm{OC}$ of soil. The probable reason for no significant changes in most of the physicochemical properties might be due to shorter time period between sowing and harvesting of the crop resisting change as soil have greater buffering capacity. The studies conducted by Badhulkar et al., (2000), Selvi et al., (2005) and Bajpai et al., (2006) clearly revealed that only long-term experimentation brought changes in fundamental physico-chemical properties of the soil.

\section{Available N, P and $K$ content in soil}

As envisaged from table 2, the amount of available NPK increased significantly by inoculation with Bacillus subtilis which was to the tune of 4.25, 6.20 and 5.07 per cent over un-inoculated plots. Tripura et al., (2016) also revealed that inoculation of cowpea seeds with Rhizobium + Phosphate Solubilizing Bacteria significantly increased the available NPK content in soil compared to un-inoculation. However, for growing substrates (soilless medium in pro-trays and soil medium in earthen pots) and different transplanting dates, there were no significant variations w. r. t. post-harvest availability of these nutrients in the soil.
The increase in available NPK contents in soil by bacterium (Bacillus subtilis) is mainly attributed to its ability to fix atmospheric nitrogen consequently leading to high accumulation of nitrogen in soil (Tripura et al., 2016), improving soil physical properties and secreting organic acids (e.g., acetic, propionic, fumaric and succinic) which help in the mineralization of soil nutrients leading to high availability of nutrients in available forms ready for uptake by plants. Also, biofertilization led to enhance the microbial activity in soil, which accelerate the decomposition of organic matter and maximize soil content of nutrients (Ewees and Hafeez, 2010).

\section{Total microbial count}

The data presented in table 2 revealed that significant high microbial population (112.57 $\times 10^{5} \mathrm{cfu} / \mathrm{g}$ ) was observed in the rhizosphere of the inoculated plants. These results are in conformation with those of Mandyal et al., (2012), who also reported that treatment of seeds with Bacillus isolate (PM9) resulted in increased microbial population in bell pepper rhizosphere over untreated control. Increased microbial population $\left(102.16 \times 10^{5} \mathrm{cfu} / \mathrm{g}\right)$ found in the rhizoshere of plant developed from seedlings raised in soilless medium in portrays than soil substrate in earthen pots $\left(98.83 \times 10^{5} \mathrm{cfu} / \mathrm{g}\right)$. However, the different transplanting dates recorded no significant difference in total microbial count.

The significantly higher population of microorganisms in rhizosphere of treated plants over the untreated ones attributed to the reason that addition of microbial inoculants revamped the soil environment which favoured the growth of soil micro flora led to improved efficacy of the applied manures and fertilizers (Kaushal et al., 2011). Further, microbial inoculants carries elevated amount of soil enzymes and plant growth hormones 
which aggrandize microbial populations and carry more nutrients over prolonged duration (Sindhu et al., 1997). The improved microbial population in plots planted with seedlings raised in soilless medium may be ascribed to the fact that seedlings were transplanted with entire root ball harbouring higher initial proliferation of microorganisms which expedite the subsequent build-up of microbial population in soil vis-a vis soil medium.

\section{References}

A.O.A.C., 1970. Official Method of Analysis of the Association of Official Analytical Chemists. Association of Official Analytical Chemists. Washington, DC.101p.

Aheer, G.M., Ahmad, K.J., and Ali, A. 1994. Role of weather in fluctuating aphid density in wheat crop. J. Agric. Res. 32, 295-301.

Anonymous, 2016. http://nhb.gov.in/areaproduction/Database-2016.pdf

Badhulkar, R.M., Wandie, W.P., Badole, and Balpande, S.S. 2000. Residual effect of long term application of FYM and fertilizer on soil properties (Vertisols) and yield of soyabean. J. Indian. Soc. Soil. Sci. 48, 89-92.

Bajpai, R.K., Chitale, S., Upadhyay, S.K, and Urkurkar, J.S. 2006. Long term studies on soil physico-chemical properties and productivity of rice wheat system as influenced by integrated nutrient management in inceptisol of Chattisgarh. J. Indian. Soc. Soil. Sci. 54(1): 24-29.

Bashan, Y., and Levanomy, H. 1990. Current status of Azospirillum inoculation technology: Azospirillum as a challenge for agriculture. Can. J. Microbiol. 36, 591-608.

Bevacqua, R.F., and VanLeeuwen, D.M. 2003. Planting date effects on stand establishment and yield of chile pepper.
J. Am. Soc. Hortic. Sci.38, 357-360.

Bhardwaj, R.K., 1993. Studies on Spacing and Time of Planting in Some Indeterminate Tomato Cultivars. M.Sc. Thesis. Department of Vegetable Science, Dr YS Parmar University of Horticulture and Forestry, Solan.141p.

Bukasov, S.M., 1930. The cultivated plants of Mexico, Guatemala and Columbia. Bulletin of Applied Botanical Genetics and Plant Breeding Supplement 47(4): 261-273.

Chand, S., Kumar, N., and Kumar, S. 2015. Effect of transplanting dates and biofertilizers on plant growth and fruit quality parameters of tomato. Int. J. Trop. Agric. 33, 3355-3360.

Chassy, A.W., Bui, L., Renoud, E.N.C., Horn, M.V., and Mitchell, A.E. 2006. Three year comparison of the content of antioxidant micro constituents and several quality characteristics in organic and conventionally managed tomatoes and bell peppers. J. Agric. Food. Chem. 54(45): 8244-8252.

Das, A.J., Kumar, M., and Kumar, R. 2013. Plant growth promoting PGPR: An alternative of chemical fertilizers for sustainable environment friendly agriculture. Res. J. Agric. For. Sci. 1, 21-23.

Ewees, M.S.A., and Hafeez, A.A.A. 2010. Response of maize grain yield to a partial substitution of $\mathrm{N}$-mineral by applying organic manure, bioinoculation and elemental sulphur as an alternative strategy to avoid the possible chemical pollution. Egypt. J. Soil. Sci. 50(1): 141-166.

Glick, B.R., 1995. The enhancement of plant growth by free living bacteria. Can. J. Microbiol. 41: 109-117.

Greenleaf, W.H., 1986. Pepper breeding. In: Breeding Vegetable Crops. AVI, West Port, pp. 67-134.

Gul, A., Ozaktan, H., Yolageldi, L., Cakir, B., 
Sahin, M., and Akat, S. 2012. Effect of rhizobacteria on yield of hydroponically grown tomato plants. In: Proceedings of IS on green system, held at Ege University, Faculty of Agriculture, Department of Horticulture, BornovaIzmir, Turkey. Pp.777-784.

Hossain, M.M., 2001. Influence of Planting Time on the Extension of Picking Period of Four Tomato Varieties. M.Sc. Thesis. Department of Horticulture, Bangladesh Agricultural University, Mymensingh. 46p.

Jackson, M.L., 1973. Soil Chemical Analysis. Prentice Hall India Private Limited, New Delhi, India. Pp.111-126.

Jeevansab, 2000. Effect of Nutrient Sources on Growth, Yield and Quality of Capsicum Growth under Different Environments. M.Sc. Thesis. University of Agricultural Science, Dharwad, Karnataka (India).

Kaushal, M., Kaushal, R., Thakur, B.S., and Spehia, R.S. 2011. Effect of plant growth-promoting rhizobacteria at varying levels of $\mathrm{N}$ and $\mathrm{P}$ fertilizers on growth and yield of cauliflower in mid hills of Himachal Pradesh. J. of Farm. Sci. 1, 19-26.

Kethran, M.R., Sun, Y.Y., Khan, S. Baloch, S.U., Wu, L.L., Lu, T.T., Yang, Y., Hu, Z., Salam, A., Iqbal, S., Ali, S., and Bashir, W. 2014. Effect of different sowing dates on insect pest population of chillies (Capsicum annuum L.). J. Bio. Agric. Healthc. 4(25): 196-214.

Kloepper, J.W., Tuzun, S., Liu, L., and Wei, G. 1993. Diversity among xanthomonads pathogens on pepper and tomato. Ann. Rev. Phytopathol. 36, 4158.

Lamsal, K., Kim, S.W., Kim, Y.S., and Lee, Y.S. 2012. Application of rhizobacteria for plant growth promotion effect and biocontrol of anthracnose caused by Colletotrichum acutatum on pepper.
Mycobiol. 40(4): 244-251.

Mandyal, P., Kaushal, R., Sharma, K., and Kaushal, M. 2012. Evaluation of native PGPR isolates in bell pepper for enhanced growth, yield and fruit quality. Int. J. Farm. Sci. 2(2): 28-35.

Merwin, H.D., and Peech, M. 1951. Exchange ability of soil potassium in the sand, silt and clay fractions as influenced by the nature and complementary exchangeable cations. Soil. Sci. Am. Proc. 15, 125-128.

Mirik, M., Aysan, Y., and Cinar, O. 2008. Biological control of bacterial spot disease of pepper with Bacillus strains. Turk. J. Agric. For. 32, 381-390.

More, S.J., Gohil, J.H., Bhanderi, D.R., Patil, S.J., and Tekale, G.S. 2014. Productivity and profitability of tomato (Lycopersicon esculentum Mill.) influenced by various transplanting dates and mulches. Trends. Biosci.7 (17): 2376-2381.

Murphy, A.K., Zehnder, G.W., Schuster, D.J., Sikora, E.J., and Kloepper, J.W. 2000. Plant growth-promoting rhizobacterial mediated protection in tomato against tomato mottle virus. Plant. Dis. 84(7): 779-784.

Olsen, S.R., Cole, C.V., Watenabe, D.S, and Dean, L.A. 1954. Estimation of available phosphorous in soils by extraction with sodium bicarbonate. US Department of Agriculture Circular 939.

Panse, V.G., and Sukhatme, P.V. 2000. Statistical Methods for Agricultural Workers. Indian Council of Agricultural Research, New Delhi, India. Pp.157165.

Peyvast, G.H., 2001. Study of some quality and quantity factors of tomato. J. Veg. Crop. Prod.10, 15-22.

Selvi, D., Santhy, P., and Dhakshinamoorthy, M. 2005. Effect of inorganic alone and in combination with farmyard manure on physical properties and productivity 
of vertic haplusteps under long-term fertilization. J. Indian. Soc. Soil. Sci.53 (3): 302-307.

Sheoran, O.P., Tonk, D.S., Kaushik, L.S., Hasija, R.C., and Pannu, R.S., 1998. Statistical software package for agricultural research workers. In: Recent Advanes in Information Theory, Statistics and Computer Application (Hooda DS and Hasija RC eds). Department of Mathematics Statistics, CCS HAU, Hisar. Pp.139-143.

Shiau, F.L., Chung, W.C., Huang, J.W., and Huang, H.C. 1999. Organic amendment of commercial culture media for Rhizoctonia damping-off of cabbage. Can. J. Plant. Pathol. 21: 368-374.

Sindhu, S.S., Suneja, S. and Ddarwall, K.R., 1997. Plant growth promoting rhizobacteria and their role in crop productivity In: Biotechnological Approaches in Soil Microorganism for Sustainable Crop Production (Dararwall KR ed). Scientific publisher, Jodhpur. Pp.149-170.

Singh, A., Jain, P.K., Sharma, H.L, and Singh, Y. 2015. Effect of planting date and integrated nutrient management on the production potential of tomato (Solanum lycopersicon Mill.) under polyhouse condition. J. Crop. Weed. 11: 28-33.

Sreelatha, D., Rao, K.L., Veeraghavairah, R., and Padmaja, M. 1997. Physiological variations in French bean cultivars as affected by sowing dates. Agric. Res.18, 111-114.

Subba Rao, N.S., 1999. Soil Microorganisms and Plant Growth. Oxford \& IBH publishing Co., New Delhi. 252p.

Subbiah, B.V., and Asija, G.L. 1956. A rapid procedure for the estimation of the available nitrogen in soils. Curr. Sci. 25, 259-60.

Sujay, Y.H., and Giraddi, R.S. 2014. Investigation on the effects of planting time and plant geometry on the activity of sucking pests of chilli Capsicum annuum L. Global. J. Sci. Front. Res.: D Agric. Vet. 14(4):1-11.

Tripura, P., Verma, R., and Kumar, S. 2016. Effect of potassium humate and bioinoculants on cowpea (Vigna unguiculata L.) influence of soil fertility, enzymatic activity and microbial population in soil. Int. J. Agric. Sci. 8(53): 2638-2641.

Vidya, G., Padma, M., and Rajkumar, M. 2013. Effect of planting time and plant densities on yield, quality and cost of production in garlic (Allium sativum L.) cv. Jamnagar. Asian. J. Hortic. 8, 552555.

Walkley, A., and Black, T.A. 1934. An estimation of soil organic matter and proposed modification of the chromic acid titration method. Soil. Sci. 37:2938 .

\section{How to cite this article:}

Kajal Sharma, A.K. Sharma and Shivender Thakur. 2017. Sweet Pepper (Capsicum annuum L.) Productivity: Quality and Soil Health in Sub-Temperate Zone of North-Western Himalayas. Int.J.Curr.Microbiol.App.Sci. 6(9): 280-288. doi: https://doi.org/10.20546/ijcmas.2017.609.035 